\title{
ORGANIC CARBON ISOTOPE PERTURBATIONS IN THE CRETACEOUS- PALEOGENE ORGANIC-RICH SEQUENCE, CENTRAL EGYPT
}

\author{
Moataz El-Shafeiy
}

Geology Department, Faculty of Science, Cairo University

\begin{abstract}
The Cretaceous-Paleogeneorganic-rich sediments of central Egypt are preserved as laterally extensive organic-rich successions that are represented mainly by the Duwi and Dakhla formations. Numerous studies were concerned their hydrocarbon source rock potential, trace metal accumulation, and molecular fossils composition. Very rare studies were concerning their organic carbon isotopic composition. The present study; however, investigates the ${ }^{\delta 13} \mathrm{C}$ of bulk organic matter as well as the ${ }^{13} \mathrm{C}$ of primary productivity tracers (pristane and phytane) for samples from two drilled cores in the Quseir and Abu Tartur areas. The results of the ${ }^{\delta 13} \mathrm{C}_{\mathrm{TOC}}$ values indicate that the organic carbon, is essentially derived from a mixture of $\mathrm{C} 3$ land-plants and marine plankton. The short-term variability in the $\delta^{13} \mathrm{C}_{\mathrm{TOC}}$ and $\delta^{13} \mathrm{C}_{\mathrm{TOC}}$ of the pristane and phytane across the Duwi Formation is mostly related to paleoecological factors and photosynthesis. The uppermost Duwi/lowermost Dakhla strata, which represent a maximum flooding surface, show a negative $\delta^{13} \mathrm{C}_{\text {TOC }}$ of magnitude -1 to $-2 \%$ and -4 to $-6 \%$ in the bulk organic carbon and bioproductivity tracers, respectively. Such perturbation can be most probably related to density stratification and overturn, although more investigations are required for the different hypotheses.
\end{abstract}

Keywords: Cretaceous-Paleogeneorganic, organic carbon, Duwi Formation, Dakhla formations

\section{INTRODUCTION}

Marine continental shelves were prevailed across North Africa during the Upper Cretaceous-Paleogene time. The sedimentation of organic-rich sediments during this time mirrors a period of high productivity on shallow shelves that mostly favored the preservation of organic matter through time (Glenn and Arthur, 1990). The resulting black shales are excellent oil source rocks, which sourced some of oil reservoirs in the Middle East (Robinson and Engel, 1993). In Egypt, these deposits are conserved as laterally extensive organic-rich successions that are represented by the Duwi and Dakhla formations in ascending order (ElShafeiy et al., 2017).

Investigating the easily extractable organic matter fraction of black shale/marl from phosphate mines (Abu Shegela and Younis) within the DuwiFormationalong the Red Sea coast of Egypt (e.g., Ganz, 1987; Ganz et al., 1990; El-Kammar, 1993; 2015) was the main objectives of several studies. Further studies were accomplished concerning the lipids based on core samples from the Duwi and Dakhla formations in the Quseir area (Red Sea) as well as in the Abu Tartur area (El-Shafeiy et al., 2014; 2017). The latter studies reported that these rocks were deposited under episodic photic zone anoxia, as indicated by the observation of aryl isoprenoids, which favored the accumulation and preservation of organic material.

It is known that the intact organic particles, which reach the sediments-water interface, preserve the carbon isotope ratio of the primary bioproducers (Galimov 2006) and therefore the $\boldsymbol{\delta}^{13} \mathrm{C}$ of organic carbon in sedimentary rock is close to thatof plankton. Rare studies investigated the ${ }^{13} \mathrm{C}$ isotopic composition for the Duwi-Dakhla organic material (e.g., Holail et al., 1995). Their $\delta{ }^{13} \mathrm{C}_{\text {org values }(-22 \% \text { o }}$ to $-28.7 \%$ ) suggested a marine source for the organic matter.

The focus of this study will be laid on the organiccarbon isotope perturbations in the transition from Late Cretaceous to the EarlyPaleogene and recorded in the organic matter. At the transition changes in sedimentology, primary productivity, and preservation of organic matter were recorded using the distribution of bulk organic, trace metal, and lipid biomarker proxies (e.g., El-Shafeiy et al, 2014; 2016; 
2017). However, the organic carbon isotope composition of these deposits and their implications were not studied in detail previously and will be the main objective of the present work. The author will focus on Abu Tartur and Quseir organic-rich sections, based on coresamples from Abu Tarturplateau area and Duwi mountain area (Fig. 1). The author will put emphasis on the ${ }^{13} \mathrm{C}$ isotopic perturbations on bulk organic material as well as lipid biomarker isoprenoids of the Duwi and Dakhla formations.

\section{GEOLOGIC SETTING}

The Cretaceous-Paleogene black shales in central Egypt are extending from Quseir-Safagaarea along the Red Sea at the East to the Dakhlaoasis at the West, passing through the Nile Valley (Fig. 1). These shales are belonging to what's called the Duwi and Dakhlaformations in ascending order.The phosphatesbearing Duwi Formation forms a part of the extensive North African phosphogenic belt (Baioumy and Tada, 2005). In addition to the phosphates, it is composed oforganic-rich shale, glauconite and/or oyster limestone (Bein and Amit, 1982; Tröger, 1984; Germann et al., 1985; Mikbel and Abed, 1985; Notholt; 1985; Ganz, 1987; Abed and Al-Agha, 1989; Glenn and Arthur, 1990; El-Kammar 1993 and references therein). The Duwi Formation was subdivided into Lower, Middle, Upper, and Uppermost members (Baioumy and Tada, 2005). The relatively deeper marine epicontinental shale/marl of the Dakhla Formation is conformably overlain the Duwi Formation (El-Shafeiy et al., 2014) and is characterized mainly by foraminifera-rich shale and/ormarl with limestone and subordinate siltstone intercalations.

Fig. 1: Satellite image for Egypt showing the two study locations (red boxes) with the boreholes marked as yellow circles (E1Shafeiy et al., 2016).

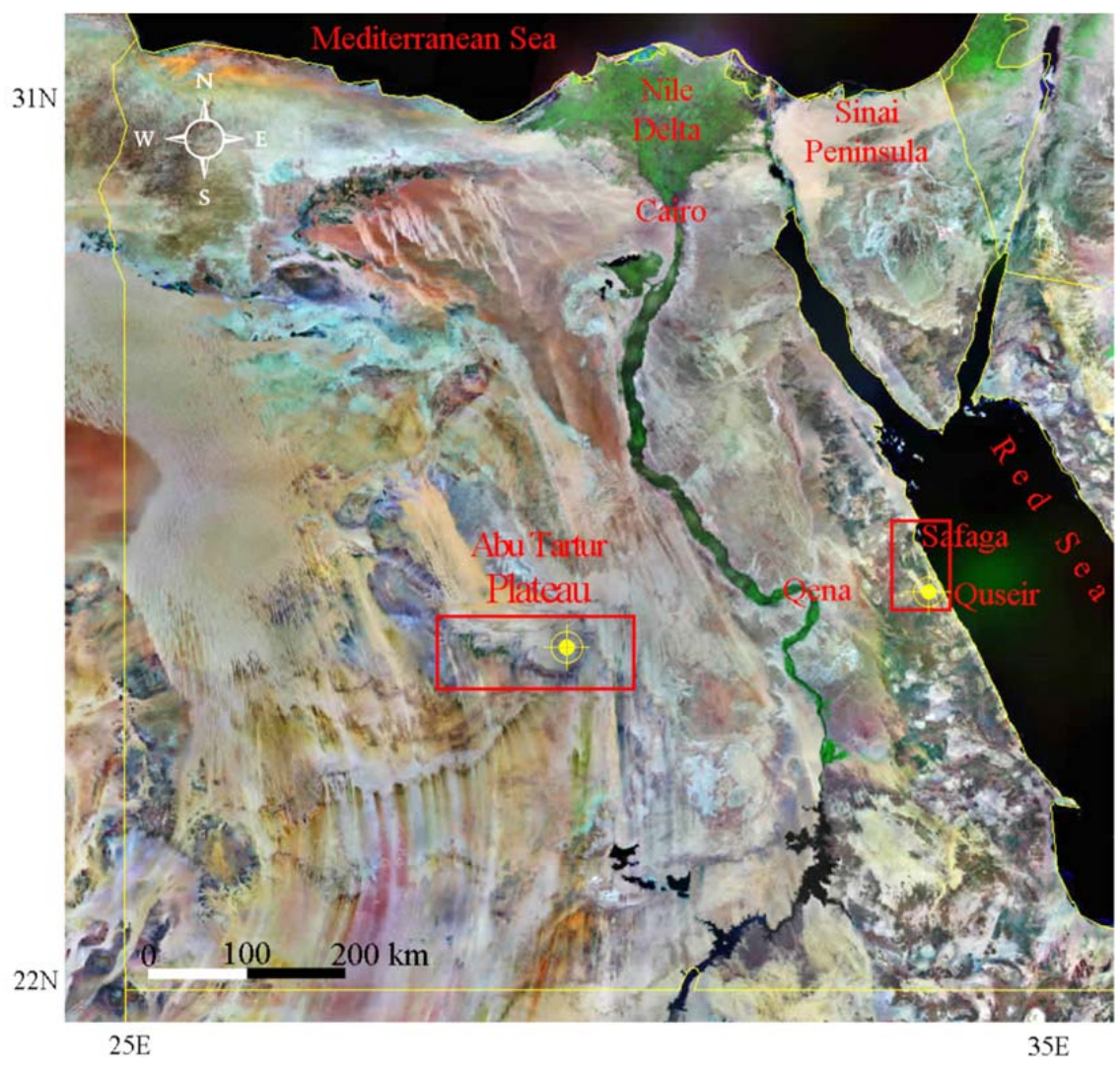

The Dakhla Formation in the Red Sea area is subdivided into the Hamama and Beida members in ascending order, separated by an unconformity demarkating the Cretaceous-Paleogene boundary (Abdel Razik, 1972; Luger, 1985; Awad et al., 1992; Zalat et al., 2008). In contrast to the Red Sea area, the Dakhla Formation in the Dakhla- Kharga landscape and the Abu Tartur Plateau has been subdivided by Awad and Ghobrial (1965) into Mawhoob, Baris and Kharga members in ascending order.

The pre-rift Cretaceous-Paleogene organic-rich sedimentary succession, along the northwestern Red Sea margin, is tilted towards the NE with numerous fault-related fold structures (Khalil and McClay, 
2002; 2009). The sediments were deposited basically by means of tectonically-induced eustatic sea level fluctuations (e.g., Hendriks and Luger, 1987; Hendriks et al., 1987; Philobbos, 1996).

The source rock characteristics of these organic-rich strata were the main objectives of several studies (e.g., Tröger, 1984; Germann et al., 1985; Glenn and Arthur, 1990; El-Kammar 1993; El-Shafeiy et al., 2014; 2017; and references therein). They vary in their source potential and organic matter quality, based on the area and stratigraphic position; however, they have all immature to marginally mature organic material.

\section{METHODOLOGY}

\section{Sampling}

Samples were collected from the conventional cores, based on the knowledge of their total organic carbon content (TOC\%) and hydrogen index (HI) that were reported in El-Shafeiy et al. (2016). The samples were ground to a suitable mesh size before analyzing them with the isotope analytical techniques.

\section{Lipid Biomarker analysis}

Extraction of easily soluble organic matter (bitumen) took place for the study samples that were measured by coupled gas chromatography with flame ionization detector (GC-FID) following the extraction procedures of (El-Shafeiy et al., 2014; 2017). Thereafter, the rock extracts were injected in the Gas Chromatography-Isotope Ratio Mass Spectrometry machine.

\section{Isotope measurements}

\section{$\delta^{13} C_{T O C}$ measurements}

The homogenized samples were attacked with $\mathrm{HCl}(10 \%)$ before the analysis for dissolving the inorganic carbon portion. Thereafter the samples were centrifuged and the supernatant $\left(\mathrm{CaCl}_{2}\right)$ was removed. This process was repeated as long as no reaction was observed. The samples then were washed with Milli-Q water several times to remove any residual $\mathrm{HCl}$. For obviously dolomitized samples, $\mathrm{HCl}$ was added in excess and was left overnight on a $50^{\circ} \mathrm{C}$ hot plate to make sure that all dolomite was dissolved. All treated and cleaned samples left overnight at $60-70^{\circ} \mathrm{C}$ for drying. The percentage of the difference in dry weight before and after the decalcification can be calculated as the total inorganic carbon (TIC\%). A specific amount of each sample was calculated (equivalent amount of 200-400 $\mu \mathrm{gTOC}$ ) and weighted in tin foil boats. The analysis was carried out using a FinniganMAT-Delta Plus instrument coupled with a Carlo-Erba element analyzer at the MARUM, University in Bremen.Carbon isotope ratios are given as $\delta$ values $\left(\boldsymbol{\delta}^{13} \mathrm{C}_{\text {TOC }}\right.$ in \%o) relative to the Vienna Pee Dee Belemnite (VPDB) standard.

\section{$\delta$ Gas-chromatography-isotope ratio mass spectrometry (GC-irMS)}

Compound-specific carbon isotope were carried out with a Thermo Electron Trace GC connected via a Thermo Electron combustion interface III to a Thermo Electron Delta-Plus XP spectrometerat the University Bremen (MARUM).Standard deviations are $<0.6 \%$. All reported compound-specific isotopic values are measured as duplicates.

\section{RESULTS AND DISCUSSION}

\section{Bulk Organic Carbon Isotope $\left(\delta^{13} \mathrm{C}_{\mathrm{TOC}}\right)$}

\section{Duwi Formation}

The bulk organic carbon isotope values of Duwi Formation are varying significantly from $-30.4 \%$ o (Uppermost Member) to $\sim-24.7 \%$ (Upper Member; Figs. $2 \& 3$ ). Despite the fact that terrestrial organic matter have lighter $\boldsymbol{\delta}^{13} \mathrm{C}_{\text {TOC }}$ values (e.g., Galimov, 2006), the relatively heavy values of the Lower Member of Abu Tartur (phosphorite) and Upper members of the two sections (Figs. 2 \& 3), although they represent typeIII to marginally IV kerogen, might be attributed to bad preservation of the organic material. This led to the degradation or oxidation of organic material by toxic or dysoxic bottom water, and altered the isotopic composition to heavier values. This is in accordance with the lithologic characteristics (e.g. 
the presence of glauconite and Oyster limestone in the Upper Member interlayered with grey shale) and proved from their elevated baseline of their chromatograms (El-Shafeiy et al., 2014). The overall $\delta^{13} \mathrm{C}_{\text {TOC }}$ values implicate that the organic matter were derived chiefly from a mixture of $\mathrm{C} 3$ land-plants and marine phytoplankton (e.g., Peters et al., 2005).

At the uppermost Duwi/lowermost Dakhla strata, where the highest TOC content and maximum flooding surface were observed (El-Shafeiy et al., 2016), negative organic carbon isotope excursions were observed of magnitude $-1 \%$ and $-2 \%$ for Abu Tartur and Quseir sections, respectively (Figs. $2 \&$ 3).Such excursions were synchronized with photic zone anoxia, as evidenced by the detection of aryl isoprenoids (El-Shafeiy et al., 2014; 2017), which are thediagenetic products of aromatic carotenoids in anoxygenic green sulfur bacteria (Chlorobiaceae) (Summons and Powell 1986; 1987). The negative values mirror a perturbation in the carbon cycle and an interruption during the carbon isotopic fractionation throughout photosynthesis.

In Abu Tartur section, with the start of the high TOC peak, the isotopic values returned back to its regular value ( $\sim 27 \%$ ) and afterwards, second negative excursion occurred (Fig. 2). This might be explained as; with the start of increasing the primary productivity (start of TOC\% increase), the isotopic values shifted to relatively positive values due to the rapid uptake of carbon inside the marine phytoplankton (type II kerogen), where the chance for isotopic fractionation decreased (Galimov, 2006).

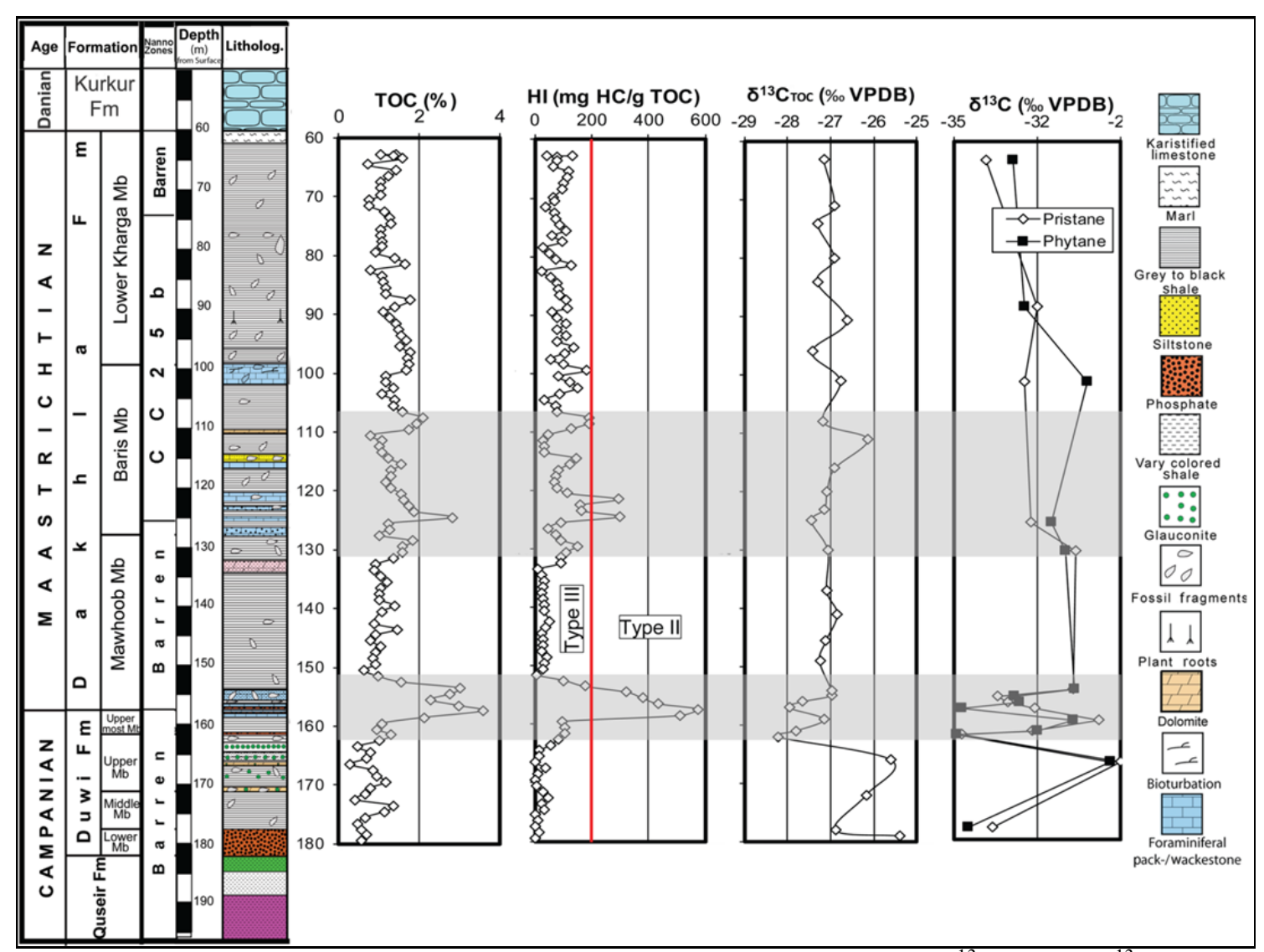

Fig. 2: Mutual distribution of TOC\% and HI from El-Shafeiy et al. (2016), $\delta^{13} \mathrm{C}_{\mathrm{TOC}}$ and $\delta^{13} \mathrm{C}$ of pristane and phytane molecular fossils of the present study for Abu Tartur section.

\section{Dakhla Formation}

Almost uniform $\delta^{13} \mathrm{C}_{\mathrm{TOC}}$ values (more or less $\sim-27 \%$ ) were observed all over the rest of the Dakhla Formation in Abu Tartur section, which are in accordance with the vertical distribution of the organic carbon content (mainly $<2 \%$ ) and hydrogen index (mainly $<200 \mathrm{mg} \mathrm{HC} / \mathrm{g}$ TOC) (Fig. 2). In the Quseir 
section; however, the $\delta^{13} \mathrm{C}_{\mathrm{TOC}}$ values show variable vertical distribution (from -28 to $-25 \%$ ) that behave accordingly with the vertical distribution of the organic carbon content and the hydrogen index (Fig. 3). No clear relation was observed between the changes in $\delta^{13} \mathrm{C}_{\mathrm{TOC}}$ values and lithostratigraphic variations.

By increasing the TOC\% and $\mathrm{HI}$, the $\delta^{13} \mathrm{C}_{\mathrm{TOC}}$ gets two heavier values (Fig. 3). The main controlling factor at this point is the efficiency of $\mathrm{CO}_{2}$ uptake during a plankton bloom in water.Here, the ${ }^{13} \mathrm{C}$-depleted biosynthesized organic matter becomes less significant due to the depletion of the bicarbonate pool in the water (Galimov, 2006). As with the aforementioned Duwi Formation, the $\delta^{13} \mathrm{C}_{\mathrm{TOC}}$ values pinpoint to organic material that are derived mainly from $\mathrm{C} 3$ land-plant and marine phytoplankton.

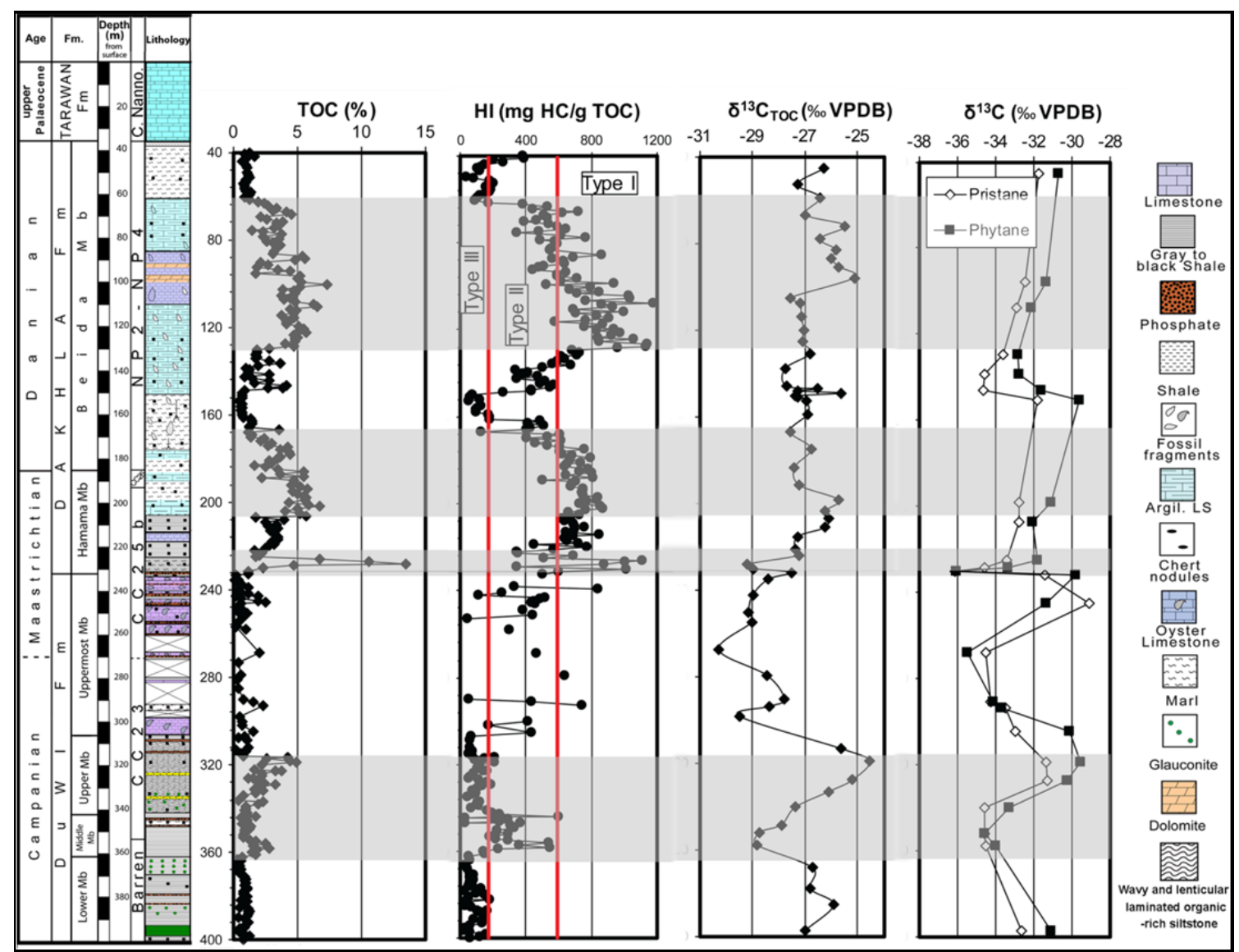

Fig. 3: Mutual distribution of TOC $\%$ and $\mathrm{HI}$ from El-Shafeiy et al. $(2016), \delta^{13} \mathrm{C}_{\mathrm{TOC}}$ and $\delta^{13} \mathrm{C}$ of pristane and phytane molecular fossils of the present study for Quseir section.

\section{Compound-Specific Carbon Isotope}

\section{Duwi Formation}

Pristane and phytane isoprenoids were selected because of their importance as tracers of photosynthesis, as they are derived from phytol side-chain of chlorophyll (e.g., Brooks et al., 1969). Additionally, there were several co-elusions of steranes and hopanes compounds (several compound are eluded at same retention time), which led to mixed isotope measurements. The vertical distribution of the $\delta^{13} \mathrm{C}$ values of the pristane and phytane isoprenoids is quite similar to that of the $\delta^{13} \mathrm{C}_{\mathrm{TOC}}$ values (Figs. $2 \&$ 3 ) with significantly lighter values, as a results of isotope fractionation during diagenesis (e.g., Galimov, 2006). The lightest values were recorded in the Middle and the Uppermost members ( -34.5\%o to -35\%) in the two sections, whereas the heaviest values were observed in the Upper Member ( $-29.3 \%$ and -29.6 to $-31.5 \%$, for $\mathrm{Abu}$ Tartur and Quseir sections, respectively).Like in $\delta^{13} \mathrm{C}_{\mathrm{TOC}}$, the uppermost Duwi/lowermost Dakhla strata have negative carbon isotope excursion of magnitude -4 to $-6 \%$ for Abu Tartur and Quseir sections, respectively (Figs. $2 \& 3$ ). Similar isotope ratios of pristane and phytane lipids 
El-Shafeiy, M.

$(\sim-32 \%$ to $-36 \%)$ were noted in Schoell et al. (1994), which are indicative of a contribution from photic zone organisms.

\section{Dakhla Formation}

The $\delta^{13} \mathrm{C}$ curves of the pristane and phytane isoprenoids are more or less parallel to that of $\delta^{13} \mathrm{C}_{\mathrm{TOC}}$ curve, which is in turn accordant with the TOC\% and HI curves (Figs. $2 \& 3$ ). The values range from $34.5 \%$ to $-29.7 \%$, which have no noticeable preference to lithology.

\section{Maximum Flooding Surface Isotope Excursion}

The limited data of the present study recorded the negative carbon isotope excursion in maximum flooding surface strata for both bulk organic carbon and molecular fossils as well (Figs. $2 \&$ 3). Since the contribution of terrestrial organic matter is minor in these strata (mostly kerogen type I or II), this excursion cannot be explained as a result of differences in the ratio of terrestrial to marine organic material.

Several authors investigated similar organic carbon isotope excursions, which were synchronized with photic zone anoxia (e.g. Küspert, 1982a\&b; Schouten et al., 2000) and maximum flooding surface (e.g., Harding et al., 2011). Küspert (1982a\&b) hypothesized that it was resulted from recycling of isotopically light $\mathrm{CO}_{2}$ in restricted and density-stratified basins. The photic zone anoxia does enhance the $\mathrm{CO}_{2}$ recycling and affects the ${ }^{13} \mathrm{C}$-contents of the bioproduced organic material (Schouten et al., 2000). Compound-specific $\delta^{13} \mathrm{C}$ values of the lipids of primary producers are paralleled to the $\delta^{13} \mathrm{C}_{\mathrm{TOC}}$ curve and imply that differences in $\delta^{13} \mathrm{C}_{\mathrm{TOC}}$ are related to differences in $\delta^{13} \mathrm{C}_{\text {lipids. }}$. The model emphasized that the degraded organic matter by anaerobic organisms in anoxic bottom-water conditions can produce isotopically light $\mathrm{CO}_{2}$, which can be accumulated below the redox boundary and can be episodically mixed with the surface water body (Schouten et al., Op. cit.). Photoautotrophic algae and bacteria used the ${ }^{12} \mathrm{CO}_{2}$ again during photosynthesis, producing ${ }^{13} \mathrm{C}$-depleted organic matter. General lipids such as pristane and phytane (derived from both eu- and pro-karyotes) follow synchronously the $\delta^{13} \mathrm{C}_{\mathrm{TOC}}$ curve and the negative shift of the bulk organic carbon, indicates that differences in $\delta^{13} \mathrm{C}$ are related to differences in aqueous $\mathrm{CO}_{2}$ or $\delta^{13} \mathrm{C}_{\text {of }} \mathrm{CO}_{2}$ in the photic zone (Schouten et al., Op. Cit.).

The present work accords with the Küspert model (1982 a\&b). On the other hand, changes in the supply of dissolved inorganic carbon by rivers could be a possibility; however, it would have interrupted the photic zone anoxia. The limited data of this study cannot demonstrate such possibility. Further inorganic carbon isotope measurements are required as a future scope. Furthermore, the hypotheses of Cohen et al. (2007) such as; methane hydrates dissociation, thermogenic methane release, cometary impact, and oxidation of marine organic carbon, are all needed to be investigated.

\section{CONCLUSIONS}

The organic matter of the Cretaceous-Paleogene sequence in central Egypt display organic carbonisotope perturbations across the Duwi- Dakhla formations. The $\delta^{13} \mathrm{C}_{\mathrm{TOC}}$ values indicate that the organic carbon is essentially derived from a mixture of $\mathrm{C} 3$ land-plants and marine phytoplankton. The Lower and Upper members (kerogen type III) of the Duwi Fm are characterized by heavier carbon isotope than the Middle and Uppermost members (kerogen type II and I). The short-term $\delta^{13} \mathrm{C}_{\mathrm{TOC}}$ Variability along the Duwi Formation indicates organic carbon isotope perturbation related to paleoecological considerations. The uppermost Duwi/lowermost Dakhla strata, which are considered as a maximum flooding surface, contain the highest TOC\% and $\mathrm{HI}$ and are synchronized with negative carbon isotope excursion.

The $\delta^{13} \mathrm{C}$ values of the primary production tracers (pristane $\&$ phytane) follow a trend similar to that of $\delta^{13} \mathrm{C}_{\mathrm{TOC}}$, indicating that differences are related to $\delta^{13} \mathrm{C}$ of $\mathrm{CO}_{2}$. This is in accordance with the hypothesis of Küspert (1982 a \& b) that the negative carbon isotope excursion resulted from the episodic recycling of isotopically light $\mathrm{CO}_{2}$, derived from the mineralization of organic matter in restricted bottom waters.It is considered doubtful that the negative shift in the $\delta^{13} \mathrm{C}$ was caused by factors such as methanogenesis, gas hydrate dissociation, or comet impact. 


\section{Organic carbon isotope perturbations in the Cretaceous-Paleogene}

\section{ACKNOWLEDGMENT}

The author would like to thank Dana Gas Company for providing the core samples. Thanks for the organic geochemistry working group in MARUM for analyzing the samples. Also, I am thankful for the fruitful revision of Prof. M. Darwish and Prof. M. El-Kammar.

\section{REFERENCES}

Abdel Razik, T., (1972): Comparative studies on the Upper Cretaceous-Early Paleogenesediments on the Red Sea Coast, Nile Valley and Western Desert, Egypt. $9^{\text {th }}$ Arab Petr. Cong. Algiers, (3B), 71-23.

Abed, A. M., Al-Agha, M. R., (1989): Petrography, geochemistry and origin of NW Jordan phosphorites. J. Geolog. Soc. London, 146, 499-506.

Awad, G. H., Ghobrial, M. G., (1965): Zonal stratigraphy of the Kharga Oasis. GeologicalSurvey Egypt, Cairo. Paper No. 34, 77pp.

Awad, M. M., Mohammad, M. H., Atia, G. M., Ramadan, F. S., (1992): Dakhla Shale, Tarawan Chalk and Esna Shale succession, Safaga and Quseir District, Egypt. Proceed. $8^{\text {th }}$ Symp. Phanerozoic Development Egypt, 69-92.

Baioumy, H. M., Tada, R., (2005): Origin of late Cretaceous phosphorites in Egypt.Cret. Res., 26, 261-275.

Bein, A., Amit, O. (1982): Depositional environment of the Senonianchert, phosphorite and oil shale sequence in Israel as deduced from their organic matter composition. Sedimentology, 29, 81-90.

Brooks, J.D., Gould, K., Smith, J., (1969): Isoprenoid hydrocarbons in coal and petroleum. Nature, 222, 257-259.

Cohen, A. S., Coe, A.L., Kemp, D. B., (2007): The Late Palaeocene-Early Eocene and Toarcian (Early Jurassic) carbon isotope excursions: a comparison of their time scales, associated environmental changes, causes and consequences. J. Geolog. Soc., 164, 1093-1108.

El-Kammar, M. M., (1993): Organic and inorganic composition of the Upper Cretaceous-Lower Tertiary black shales from Egypt and their hydrocarbon potentialities. Ph.D Thesis, Faculty of Sciences, Cairo Univ., 227p.

El-Kammar, M. M., (2015): Source-rock evaluation of the Dakhla Formation black shale in Gebel Duwi, Quseir area, Egypt. J. Afr. Ear. Sci., 104, 19-26.

El-Shafeiy, M., Birgel, D., El-Kammar, A., El-Barkooky, A., Wagreich, M., Omar Mohamed, Peckmann, J. (2014): Palaeoecological and post-depositional changes recorded in Campanian-Maastrichtian black shales, Abu Tartur plateau, Egypt. Cret. Res., 50, 38-51.

El-Shafeiy, El-Kammar, A., El-Barkooky, A., Meyers, P., (2016): Paleo-redox depositional conditions inferred from trace metal accumulation in two Cretaceous-Paleocene organic-rich sequences from Central Egypt. Mar. and Pet. Geol., 73, 333-349.

El-Shafeiy, M., Birgel, D., El-Kammar, A, El-Barkooky, A., Wagreich, M., SamehTahoun,Peckmann, J., (2017): Integrated palaeo-environmental proxies of the Campanian to Danian organic-rich Quseir section, Egypt. Mar. and Pet. Geol., 86, 771-786.

Galimov, E. M., (2006): Isotope organic geochemistry. Org. Geochem., 37, 1200-1262.

Ganz, H., (1987): Geochemical evaluation of hydrocarbon source rock characteristics and facies analysismethods and application. Berliner Geowissen. Abhand. (A), 75.3, 669-690.

Ganz, H., Luger, P., Schrank, E., Brooks, P. W., Flower, M.G., (1990): Facies evolution of late Cretaceous black shales from Southeast Egypt. Berliner Geowissen. Abhand. (A), 120.2, 933-1010.

Germann, K., Bock, W. D., Schröter T., (1985): Properties and origin of Upper Cretaceous Campanian phosphorites in Egypt. Sci. Geol. Mem., 77, 23-33.

Glenn, C., Arthur, A., (1990): Anatomy and origin of a Cretaceous phosphorite-greensand giant, Egypt. Sedimentology, 7, 132-154.

Harding, I.C., Charles, A.J., Marshall, J.E.A., Pälike, H., Roberts, A.P., Wilson, P.A., Jarvis, E., Thorne, E., Morris, E., Moremon, R., Pearce, R.B., Akbari, S., (2011):Sea-level and salinity fluctuations during the Paleocene-Eocene thermal maximumin Arctic Spitsbergen. Earth \& Planet. Sci. Lett., 303, 97-107.

Hendriks, F., Luger, P., (1987): The Rakhiya Formation of the Gebel Qreiya area: evidence of Middle Campanian to early Maastrichtian synsedimentary tectonism. Berliner Geowissen. Abhand., (A) 75, 83-89. 
Hendriks, F., Luger, P., Biwitz, J., Kallenbach, H., (1987): Evolution of the depositional environments of SE Egypt during the Cretaceous and lower Tertiary. Berliner Geowissen.Abhand. (A) 75, 49-82.

Holail, H., AbdAlla, M., El Dahhar, M., (1995): Mineralogical and geochemical evaluation of Upper Cretaceous black shales, SafagaDistrct, Egypt. Qatar Univ. Sci. J., 15(1), 205-214.

Khalil, S.M., McClay, K.R., (2002):Extensional fault-related folding, northwestern Red Sea, Egypt. J. Str. Geo., 24, 743-762.

Khalil, S. M., McClay, K. R., (2009). Structural control on syn-rift sedimentation, northwestern Red Sea margin, Egypt. Mar. and Pet. Geo., 26, 1018-1034.

Küspert, W., (1982a): Faciestypen des Posidonienschiefers (Toarcium, Süddeutschland). Eine isotopengeologische, organisch-chemische und petrographische Studie: Ph. D. thesis, Universität Tübingen, $232 \mathrm{pp}$.

Küspert, W., (1982b): Environmental changes during oil shale deposition as deduced from stable isotope ratios, In Einsele, G., and Seilacher, A., (editors): Cyclic and Event Stratification: Heidelberg, Springer, 482-501.

Luger, P., (1985): Stratigraphie der marinen Oberkreide und des Alttertiars im südwestlichenObernilBecken (SW-Ägypten) unter besonderer Berücksichtigungder Mikropaläontologie, aläokologie und Paläogeographie. Berliner Geowissen.Abhand., 63, 1-150.

Mikbel, S., Abed, A. M., (1985): Discovery of large phosphate deposits in NW Jordan. Dirasat, 12, 125136.

Notholt, A. J. G., (1985): Phosphorite resources in the Mediterranean (Tethyan) phosphogenic province: A progress report: Sciences Geologiques-Memoires, 77, 9-21.

Peters, K. E., Walters, C. C., Moldowan, J. M., (2005): The Biomarker Guide, $2^{\text {nd }}$ ed. Cambridge Univ. Press, Cambridge.

Philobbos, E. R., (1996): The phosphatic sediments of the Nile Valley and Eastern Desert in view of the U. Cretaceous-L. Tertiary sedimentation tectonics. Geo. Soc. Egy., Spec. Publ. (2), 313-352.

Robinson, V., Engel, M., (1993): Characterization of the source horizons within the Late Cretaceous transgressive sequence of Egypt. In: Katz, B., Pratt, L. (Eds.), Source rocks in a sequence stratigraphic framework, Studies in Geology, AAPG, 101-117.

Schouten, S., Van Kaam-Peters, H.M.E., Rijpstra, W. I.C., Schoell, M., Sinninghe Damste, J. S., (2000): Effects of an oceanic anoxic event on the stable carbon isotopic composition of early Toarcian carbon. Americ. J. Sci., 300, 1-22.

Schoell, M., Hwang, R. J., Carlson, R. M. K., Welton, J. E., (1994): Carbon isotopic composition of individual biomarkers in gilstonites (Utah). Org. Geochem., 21, 673-83.

Summons, R.E., Powell, T.G., (1986): Chlorobiaceae in Palaeozoic sea revealed by biological markers, isotopes, and geology. Nature, 319, 763-765.

Summons, R. E., Powell, T. G., (1987): Identification of aryl isoprenoids in a source rock and crude oils: biological markers for the green sulfur bacteria. Geochim. et Cosmochim. Acta, 51, 557-566.

Tröger, U., (1984): The oil shale potential of Egypt, Berliner Geowissen.Abhand. (A), 50, 375-380.

Zalat, A. A., Ramadan, F. S., El Safori, Y.A., (2008): Campanian-Paleocene facies, depositional environments and paleoclimitic conditions along the Red Sea coast, Egypt. $3^{\text {rd }}$ Environ. Conf. Fac. Sci., Zagazig Univ., 187-225. 
اضطرابات نظائر الكريون العضوي في تتابع رواسب عصر الطباشيري - الباليوجين الغنية عضويا فى وسط مصر معتز الثافعي

\section{قسم الجيولوجيا-كلية العلوم -جامعة القاهرة}

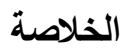

ان رواسب عصرى الطباشيري العلوى الى الباليوجين الغنية بالمواد العضوية في وسط مصر محفوظة كتتابع غني بالمواد العضوية واسعة النطاق تتمنل بشكل أساسي في مكونى الضوى والداخلة . يوجد العديد من الدراسات التى تتعلق بإحتماليتها كصخور مصدر، وتراكم الفلزات النادرة ، وتركيب الحفريات الجزيئية. بينما هناك دراسات نادرة جدا تتعلق بتكوين نظائر pristane) الكربون العضوي • تبحث الدراسة الحالية في و لعhytane لعينات اسطوانية لبية من انثين من الابار الضحلة في منطقتى القصير وأبو طرطور . تثير نتائج قيم العديم البحرية ـ إن التباين قصير الددى في قيم pristane و

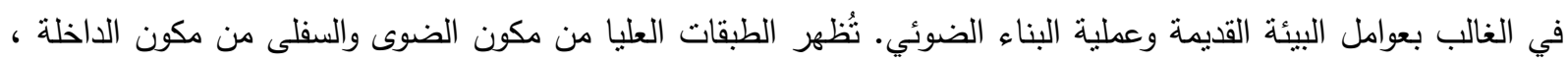

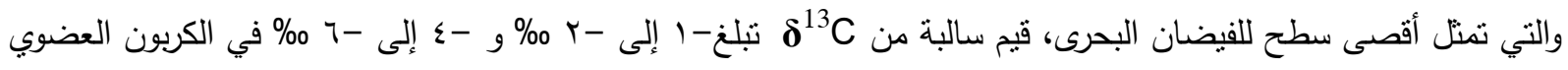

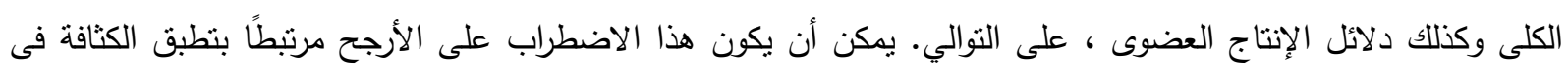

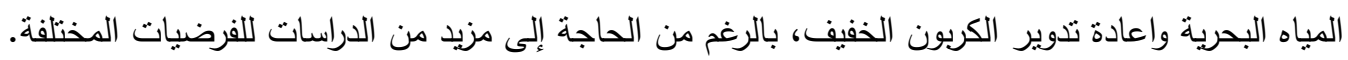

